\author{
Agata Jaśkowiec, Łukasz Kopiński, Eugenia Czernyszewicz*
}

\title{
SYSTEMY ZARZĄDZANIA JAKOŚCIĄ NA LOTNISKACH
}

Z a r y s t r e ś c i: Zapewnienie bezpieczeństwa wymaga spełnienia wymagań prawnych oraz wdrożenia systemów zarządzania w obszarze bezpieczeństwa i jakości świadczonych usług. Podnoszenie tej poprzeczki jest niezmiernie ważne, ponieważ konkurencja pomiędzy portami lotniczymi jest wielka.

Celem pracy jest ukazanie systemów zarządzania jakością w portach lotniczych. Zastosowano metodę krytycznego przeglądu literatury oraz studium przypadku. Opisane zostały systemy funkcjonujące w Międzynarodowym Porcie Lotniczym Katowice w Pyrzowicach.

S ło w a k l u c z o w e: systemy zarządzania jakością, port lotniczy, jakość

K 1 a s y fik a c j J E L: L 21

\section{WSTEPP}

Ciągły rozwój infrastruktury transportu lotniczego sprawia, że pasażerowie mają nowe wymagania $\mathrm{w}$ aspekcie oferowanych usług przez porty lotnicze. Transport ten staje się coraz częściej wybieranym środkiem przemieszczania się, na co wskazują statystyki ruchu lotniczego. Różnorodność oferowanych usług stymuluje wzrost oczekiwań klientów, nie tylko ze względu na cenę, ale przede wszystkim ich jakość oraz poziom bezpieczeństwa. O sukcesie danego lotniska decydują ich użytkownicy - ważne jest, aby podejmować wszelkie starania, mające na celu zrozumienie ich potrzeb oraz nadążenia za zmiennymi wymaganiami. Wprowadzanie systemów zarządzania usprawnia i umożliwia proces podnoszenia jakości usług. Ważnym elementem podejmowanych

\footnotetext{
* Adres do korespondencji: Agata Jaśkowiec, Łukasz Kopiński, Eugenia Czernyszewicz, Uniwersytet Przyrodniczy w Lublinie, Wydział Ogrodnictwa i Architektury Krajobrazu, Zakład Ekonomiki Ogrodnictwa, al. Akademicka 13, 20-400 Lublin, e-mail: jaskowiec1994@gmail.com;
} 
działań jest wdrożenie systemu zarządzania jakością. Według normy ISO 9001: 2015 jest to ,zestaw wzajemnie powiązanych lub wzajemnie obowiązujących elementów służących ustanawianiu polityki i celów oraz osiąganiu tych celów, wykorzystywany do kierowania organizacją i jej nadzorowania w odniesieniu do jakości”[Norma PN-EN ISO 9001: 2015]. W portach lotniczych ważny jest również system zarządzania bezpieczeństwem oraz polityka bezpieczeństwa. Odgrywają one ogromną rolę w kształtowaniu wizerunku lotniska.

\section{POLITYKA JAKOŚCI LOTNICTWA}

Polityka jakości to zespół norm i standardów dotyczących jakości wdrożonych przez dany podmiot. Każdy taki podmiot funkcjonujący w sektorze lotniczym i wykonujący określone usługi zobowiązany jest do ich świadczenia na najwyższym poziomie. Wdrożenie systemu zarzadzania jakością umożliwia świadczenie wysokiej jakości usług.

Kontrola Jakości ma na celu zbadanie przez właściwy organ urzędowy stosunku do danego podmiotu, czy i w jakim zakresie polityka jakości jest przestrzegana oraz czy i w jakim zakresie potrzebne są działania naprawcze lub korygujące. W międzynarodowym prawie lotniczym (załącznik nr 15 do konwencji chicagowskiej) zarządzanie jakością określa się, jako „skoordynowane działania dotyczące kierowania organizacją i jej nadzorowanie w odniesieniu, do jakości" [PN-EN ISO 9001:2015].

Władze lotniska podejmują wszystkie możliwe działania w celu wprowadzenia odpowiednio zorganizowanego systemu jakości zawierającego procedury, procesy oraz zasoby niezbędne do zarządzania jakością na wszystkich szczeblach funkcyjnych. System jakości powinien spełniać wymagania normy ISO 9001 oraz powinien być certyfikowany przez upoważnioną jednostkę certyfikacyjną. Wprowadzony system jakości powinien gwarantować, że rozpowszechniane informacje lotnicze spełniają określone wymagania jakości - dokładności i spójności oraz umożliwiają śledzenie ich pochodzenia za pomocą odpowiednich procedur, na każdym etapie przygotowania lub modyfikacji danych. Przyjmowanie przez podmioty lotnicze norm międzynarodowych ISO sprawia, że jakość świadczonych usług stale rośnie [Sztucki, Gąsior, Zając, Szczelina, 2011]. Podstawowymi celami osiąganymi przez wdrożenie i certyfikowanie w portach lotniczych systemów zarządzania jakością są:

- dążenie do usystematyzowania i doskonalenia systemów zarządzania,

- $\quad$ spełnienie wymagań międzynarodowych np. wdrożenie Systemu Zarządzania Jakością w Służbie Informacji Lotniczej,

- $\quad$ uzyskanie certyfikatu stanowiący istotny element promocji [Duszewski, 2016]. 
Porty lotnicze wdrażają politykę jakości w celu zwiększenia zadowolenia swoich klientów. Wśród czynników, które powodują polepszenie oferowanych usług na lotniskach możemy wymienić: wzmożona efektywna kontrola jakości, zwiększenie wymogów bezpieczeństwa oraz pojawienie się znacznej konkurencji. Za realizację zadań związanych, z jakością usług dużą odpowiedzialnością obarczone są służb pracujące na lotniskach. Straż Graniczna oraz Służba Ochrony Lotniska czuwa nad zapewnieniem wysokiej jakości bezpieczeństwem między innymi poprzez obsługę pasażerów, a także kontrolę bezpieczeństwa i odprawę bagażową [Sztucki, Gąsior, Zając, Szczelina, 2011].

\section{KRAJOWY PROGRAM KONTROLI JAKOŚCI W ZAKRESIE OCHRONY LOTNICTWA CYWILNEGO}

Istotnym elementem w dziedzinie jakości usług lotniczych jest Rozporządzenie Ministra Infrastruktury z dnia 10 stycznia 2005 r. w sprawie Krajowego Programu Kontroli Jakości w zakresie ochrony lotnictwa cywilnego. Powstał on by kontrolować oraz wskazywać zmiany w Krajowym Programie Ochrony Lotnictwa Cywilnego. Określa on na poziomie krajowym metody kontroli jakości w zakresie ochrony portów lotniczych przed atakami bezprawnej ingerencji [Rajchel, Grenda, Nowak, 2014].

Czynności kontroli jakości, które realizują audytorzy, aby określić stan jakości systemu ochrony portu lotniczego:

- audyt ochrony - procedura lub proces, którego celem jest kontrolowanie kompatybilności stanu ochrony portu lotniczego; z przepisami Krajowego Programu Ochrony Lotnictwa.

- przegląd ochrony - weryfikacja poszczególnych elementów w sferze ochrony lotniska, celem ustalenia potrzeb tego systemu. Dotyczy ona identyfikacji nieprawidłowości, które mogłyby doprowadzić do wystąpienia aktu bezprawnej ingerencji, pomimo zastosowania metod, środków i procedur ochrony lotnictwa cywilnego;

- $\quad$ inspekcja ochrony - kontrola poszczególnych elementów w sferze systemu ochrony lotniska, celem ustalenia zgodności z regulacjami prawnymi;

- badania systemu ochrony - badania realizowane w przypadku: wystąpienia sytuacji kryzysowej w lotnictwie cywilnym, nieodpowiedniego działania środków i norm ochrony lub zalecanych praktyk wynikających $\mathrm{z}$ regulacji międzynarodowych $\mathrm{w}$ celu wyjaśnienia ich zaistnienia oraz uniknięcia ich powtórzenia poprzez wprowadzenie działań naprawczych [Kalinowski, 2009]. 


\section{AUDYT BEZPIECZEŃSTWA}

Audyt bezpieczeństwa lotniczego jest procedurą, podczas której upoważnione i wykwalifikowane osoby systematycznie i obiektywnie sprawdzają uwzględnienie problematyki bezpieczeństwa $\mathrm{w}$ działalności państwa lub danej organizacji lotniczej. Powinien on dostarczać kierownictwu informacji, w oparciu, o które można podjąć działania prowadzące do poprawy stanu bezpieczeństwa. Audyt ten polega na okresowym sprawdzeniu zgodności funkcjonowania danej organizacji z systemem zarządzania bezpieczeństwem. Ich zadaniem jest sprawdzenie czy struktura organizacji, stan zatrudnienia oraz przygotowania kadry są zgodne z ustalonymi przepisami i procedurami. Podczas przeprowadzania audytów bezpieczeństwa sprawdza się, czy stosowane procedury zapewnia odpowiedni poziom bezpieczeństwa i umożliwia osiągnięcie założonych celów. Audyt ten może być prowadzony na poziomie międzynarodowym, państwowym oraz organizacji lotniczej [Klich, 2011].

Po dokonaniu czynności audytowych sporządzany jest raport końcowy przez przewodniczącego zespołu audytowanego. Raport końcowy zawiera charakterystykę stwierdzonych uchybień dotyczących stanu faktycznego ochrony lotniska w stosunku do obowiązujących regulacji prawnych. Definiuje on zalecenia i wnioski po audytowe wraz ze wskazaniem działań korygujących, które zobligowane są podjąć komórki odpowiedzialne za stan ochrony w porcie lotniczym [Rozporządzenie Ministra Infrastruktury z dnia 10 stycznia 2005r.].

\section{POLITYKA BEZPIECZEŃSTWA}

Polityka bezpieczeństwa odzwierciedla filozofię organizacji w zakresie zarządzania bezpieczeństwem i jest fundamentem, na którym zbudowany zostanie system zarządzania bezpieczeństwem. Za politykę bezpieczeństwa odpowiada szczebel kierowniczy. Zaangażowanie zarządu w kwestie bezpieczeństwa powinno być sformalizowane poprzez ogłoszenie odpowiedniej deklaracji na temat polityki bezpieczeństwa. Deklaracja ta powinna być odzwierciedleniem wymagań kierownictwa dotyczących realizacji zadań w zakresie szkolenia, wykonywania lotów, obsługi sprzętu, zabezpieczenia itp. Polityka określa, co organizacja chce osiągnąć i w jaki sposób zamierza to uzyskać. Opracowanie polityki bezpieczeństwa powinno odbywać się z pracownikami na stanowiskach najistotniejszych z punktu widzenia bezpieczeństwa. Powinna spełniać warunki takie jak:

- $\quad$ być powszechną i stosowaną przez wszystkich pracowników,

- $\quad$ podlegać okresowej weryfikacji,

- współgrać z polityką stosowaną w innych obszarach operacyjnych [Klich, 2011],

- $\quad$ zobowiązywać się do dążenia osiągniecia najwyższych standardów bez- 
pieczeństwa,

- $\quad$ spełniać wszystkie stosowne wymagania prawne oraz przestrzegać obowiązujących standardów,

- $\quad$ uwzględniać najlepsze praktyki i zapewniać odpowiednie środki [Załęski, Saletra, Kowalska, 2015].

\section{SYSTEM ZARZĄDZANIA BEZPIECZEŃSTWEM}

Systemu Zarządzania Bezpieczeństwem - (Safety Management System - SMS) opracowany został przez Międzynarodową Organizację Lotnictwa Cywilnego. Wdrażany program obejmuje zasady organizacyjne oraz wytyczne funkcjonalne systemu zarządzania bezpieczeństwem [http:// www.amw.gdynia.pl/library/File/ZN\%202010/16Zielinski\%20M.pdf ?PHPSESSID=bd4f5e989e2d5863870e23c6e1857209].

Jest to sformalizowany zbiór zasad postępowania i procedur bezpieczeństwa, stosowany przez struktury organizacyjne, połączone odpowiednimi relacjami. SMS wymaga posiadania w organizacji lotniczej struktury organizacyjnej do zarządzania bezpieczeństwem. Musi ona posiadać takie zdolności jak: generowanie celów w zakresie bezpieczeństwa, stosowanie procedur audytu i kontroli, identyfikacji zagrożeń oraz wprowadzania działań korygujących i naprawczych, a także ciągle doskonalić się w zakresie bezpieczeństwa. Celem tego systemu jest wskazanie i wdrożenie zasad bezpieczeństwa, które gwarantują osiągniecie wysokiego poziomu wydajności organizacji. Rada Organizacji Międzynarodowego Lotnictwa Cywilnego wymaga od zarządzających organizacjami lotniczymi wdrożenia Systemu Zarządzania Bezpieczeństwem celem zapewnienia bezpieczeństwa rozumianego, jako stan, w którym ryzyko wystąpienia niebezpieczeństwa jest zredukowane do akceptowalnego poziomu, bądź poniżej tego poziomu i jest utrzymywane w takim stopniu poprzez zarządzanie i identyfikację zagrożeń i ryzyka [Compa, Rajchel, Załęski, 2013]. Wdrożenie i uzyskanie certyfikatu Systemu Zarządzania Bezpieczeństwem było obowiązkiem zarządzającego lotniskiem do dnia 25 listopada 2005 roku [Duszewski, 2016].

\section{CERTYFIKACJA LOTNISK}

Wraz z wejściem w życie Rozporządzenia Komisji (UE) NR 139/2014 z dnia 12 lutego 2014r. ustanawiającego wymagania oraz procedury administracyjne dotyczące lotnisk oraz $\mathrm{z}$ rozporządzeniem Parlamentu Europejskiego i Rady (WE) ustanawiającego wymagania oraz procedury administracyjne dotyczące lotnisk zgodnie $\mathrm{z}$ Rozporządzeniem Parlamentu Europejskiego i Rady (WE) nr 216/2008 z dnia 20 lutego 2008 r. 
w sprawie wspólnych zasad w zakresie lotnictwa cywilnego i utworzenia Europejskiej Agencji Bezpieczeństwa Lotniczego, wprowadzony został na poziomie unijnym nowy system certyfikacji, oparty na nowych zasadach $\mathrm{i}$ procedurach ustanowionych $\mathrm{w}$ wyżej wymienionym rozporządzeniu.

Nowy system unijnej certyfikacji odzwierciedla nie tylko najnowszy stan wiedzy i najlepsze praktyki w zakresie lotnisk, obowiązujące normy i zalecane praktyki Organizacji Międzynarodowego Lotnictwa Cywilnego (ICAO), ale przede wszystkim zapewnia proporcjonalność wymogów eksploatacyjno-technicznych w zależności od wielkości i nasilenia ruchu, kategorii i złożoności danego lotniska oraz charakteru i zakresu prowadzonych na nim operacji. Zapewnia także niezbędną elastyczność przepisów indywidualnie do każdego lotniska.

Decyzję o wydaniu unijnego certyfikatu lotniska (po raz pierwszy lub w drodze konwersji istniejącego certyfikatu krajowego) wydaje się na wniosek zarządzającego lotniskiem, po spełnieniu wymogów określonych w szczególności w rozporządzeniu 139/2014.

Do dnia 31 grudnia 2017 r. wszystkie lotniska użytku publicznego, obsługujące zarobkowy przewóz lotniczy, na których prowadzi się operacje podejścia lub odlotu przy wykorzystaniu procedur instrumentalnych, które dysponują utwardzoną drogą startową o długości, co najmniej 800 metrów, będą musiały dostosować się do wymagań Unii Europejskiej i przejść proces konwersji certyfikatów [http://www.ulc.gov.pl/p1/247-aktualnosci/3714-pierwszy-certyfikat-lotniska-uzytku-publicznego-wydany-na-podstawie-nowych-przepisow-unijnych].

\section{POLITYKA JAKOŚCI W ZINTEGROWANYM SYSTEMIE ZARZĄDZANIA}

Problematyka jakości oraz zarządzania jakością zyskała na znaczeniu, kształtują ją między innymi:

- jakość dostępnych na rynku usług służących do zaspokojeniu potrzeb ludzkości;

- $\quad$ jakość otaczającego środowiska przyrodniczego, odzwierciedlana stopniem zanieczyszczenia poszczególnych komponentów środowiska (woda, powietrze, gleba);

- jakość środowiska pracy, zapewniająca komfort i bezpieczeństwo w trakcie wykonywania pracy [Łunarski, 2008].

W skład zintegrowanego systemu zarządzania wchodzą następujące znormalizowane systemy zarządzania:

- $\quad$ PN-EN ISO 9001: 2015 Systemy zarządzania jakością. Wymagania;

- $\quad$ PN-EN ISO 14001: 2005 Systemy zarządzania środowiskowego. Wymagania i wytyczne stosowania; 
- $\quad$ PN - N 18001: 2004 System zarządzania bezpieczeństwem i higieną pracy. Wymagania;

Odbiorcami zintegrowanego systemu jest organizacja, w tym przypadku są to lotniska.

Wymienione normy są polskimi odpowiednikami norm europejskich (z wyjątkiem normy dotyczącej bezpieczeństwa i higieny pracy, który jest normą krajową) i stanowią podstawę zewnętrznej certyfikacji systemów przez akredytowane jednostki certyfikujące [Ejdys, Kobylińska, Lulewicz-Sas, 2012].

Systemy zarządzania jakością, zarządzania środowiskowego oraz zarządzania bezpieczeństwem i higieną pracy opierają się na koncepcji stałego doskonalenia, której twórcą był Edward Deming [Latzko, Sanders, 1998].

Ważnym zagadnieniem przy wdrażaniu zintegrowanego systemu zarządzania jest ujednolicenie dokumentacji systemowej, a nadrzędnym dokumentem systemu jest polityka zintegrowanego systemu zarządzania. Zgodnie z wymogami norm ISO 9001, 14001 oraz PN 18001 zintegrowana polityka jakości, środowiskowa a także bezpieczeństwa i higieny pracy powinna zobowiązywać się do:

- $\quad$ spełnienia wymagań i ciągłego doskonalenia skuteczności systemów zarządzania jakością;

- $\quad$ zapewnienia odpowiednich zasobów i środków do wdrażania polityki jakości;

- ciągłego doskonalenia działalności w zakresie bezpieczeństwa i higieny pracy;

- $\quad$ podnoszenie kwalifikacji oraz uwzględniania roli pracowników i ich zaangażowania do działań na rzecz ochrony środowiska oraz bezpieczeństwa i higieny pracy [Ejdys, Kobylińska, Lulewicz-Sas].

\section{MIĘDZYNARODOWY PORT LOTNICZY KATOWICE W PYRZOWICACH}

Górnośląskie Towarzystwo Lotnicze Spółka Akcyjna w Katowicach 1 maja 1994 roku przejęła zarząd nad Międzynarodowym Portem lotniczym Katowice w Pyrzowicach. Podstawowym celem spółki jest zarządzanie portem lotniczym w sposób zapewniający bezpieczeństwo, efektywność i komfort użytkownikom lotniska. GTL S.A. realizuje powyższe cele poprzez wypełnianie prawnych standardów operacyjnych i organizacyjnych, w tym utrzymanie i rozbudowę infrastruktury Katowice Airport. Realizacja inwestycji, ukierunkowanie na rozwój ruchu biznesowego, dalsze dążenie do umacniania pozycji lotniska w Katowicach, jako centrum charterowe, a także ciągłe podnoszenie jakości świadczonych usług, satysfakcji podróżnych, przewoźników oraz pracowników Katowice Aiport, mają na celu przygotowanie portu w zakresie operacyjnym, organizacyjnym i kadrowym do dalszego rozwoju. Tak określone prioryte- 
ty pozwalają osiągnąć pozycję nowoczesnej i otwartej na potrzeby pasażerów i przedsiębiorców Spółki, której jednym z celów jest świadczenie usług o najwyższym standardzie. Potwierdzeniem tych dążeń jest wdrożenie Zintegrowanego Systemu Zarządzania wg norm PN-EN ISO 9001, PN-EN ISO 14001 oraz PN-N 18001 [http://gtl.com.pl/].

\subsection{Polityka Zintegrowanego Systemu Zarządzania Katowice Airport}

Kreowanie i doskonalenie skutecznych instrumentów zarządzania ukierunkowanych na satysfakcję klientów, dbałość o otaczające środowisko oraz bezpieczeństwo pracowników i wszystkich innych osób mogących być narażonych na niezamierzone zagrożenia powstające w wyniku realizowanych statutowych działań - to główne cele zarządzających lotniskiem. Posiadając pełną świadomość, co do znaczenia powyższych dziedzin zarządzana troska o ich wypełnienie znalazła przełożenie w strategii działania Górnośląskiego Towarzystwa Lotniczego, stanowiącej wyznaczniki planów i zamierzeń [http:// www.katowice-airport.com/download/gtl_polityka_jakosci.pdf].

Wykorzystywane tutaj są uznane w kraju i na świecie profesjonalne praktyki organizacyjne i techniczne zmierzające do doskonalenia w dziedzinie zarządzania Międzynarodowym Portem Lotniczym Katowice.

Wdrożenie Zintegrowanego Systemu Zarządzania w MPL Katowice ma na celu udoskonalenie:

- $\quad$ bezpieczeństwa świadczonych usług;

- zapobieganie wypadkom, chorobom zawodowy, awariom i innym sytuacjom niepożądanych, mogącym spowodować utratę zdrowia i życia pracowników, klientów i innych osób przebywającym na terenie portu lotniczego;

- obsługi pasażerów i przewoźników;

- zapobieganie zanieczyszczeniom środowiska.

System zapewnia skuteczne działania nie tylko w obszarze identyfikacji i stosowania zewnętrznych, jak i wewnętrznych przepisów, lecz również w procesach rozpoznawania, uwzględniania oraz wdrażania rosnących oczekiwań stawianych przez strony zainteresowane działalnością lotniska. Wykreowane mechanizmy zarządzania przy racjonalnym gospodarowaniu potencjałem ludzkim, technicznym, intelektualnym i finansowym pozwalają na utrzymanie wiarygodnego i utrzymującego standardy wizerunku portu lotniczego [http://www.katowiceairport.com/download/gtl_polityka_jakosci.pdf]. 


\subsection{Polityka bezpieczeństwa}

Podstawowym celem Górnośląskiego Towarzystwa Lotniczego S.A., jako zarządzającego Międzynarodowym Portem Lotniczym Katowice, jest rozwój Portu oraz dbałość o wysoki standard świadczonych usług.

Cel ten jest osiągany poprzez rozbudowę infrastruktury, zaangażowanie wykształconej kadry i wykorzystanie nowoczesnych technologii przy zachowaniu nadrzędnej zasady, jaką jest zapewnienie praktycznie możliwego i akceptowalnego poziomu bezpieczeństwa, zgodnego $\mathrm{z}$ krajowymi i międzynarodowymi standardami. Zarządzający zobowiązują się do ciągłego polepszania stanu bezpieczeństwa.

Społeczność lotniskowa ma za zadanie przyczyniać się swoim działaniem do przestrzegania i podnoszenia standardów bezpieczeństwa. Personel lotniska, użytkownicy i kontrahenci wspierają wdrażanie i rozwijanie polityki bezpieczeństwa w MPL Katowice.

Zarząd, kadra kierownicza i wszyscy pracownicy są odpowiedzialni za realizację zadań z zakresu bezpieczeństwa i za zapewnienie, że wszelkie obowiązujące standardy bezpieczeństwa są przestrzegane i stosowane. Bezpieczeństwo operacji lotniczych traktowane, bowiem są na równi $\mathrm{z}$ interesem handlowym spółki, czyniąc je priorytetowym celem strategii rynkowej i organizacyjnej.

[https://www.katowiceairport.com/pl/lotnisko/polityka-bezpieczenstwa].

\section{PODSUMOWANIE}

Klienci coraz częściej zwracają uwagę na to, co dzieje się w portach lotniczych. Wybierają lotniska, które są dla nich wygodne i komfortowe. Oczekiwania osób korzystających z portów lotniczych są bardzo różne i nie zawsze można im sprostać. Ważne jest, aby wprowadzać nowe systemy, które poprawią jakość oferowanych usług. System Zrządzania Jakością oparty na wymaganiach normy ISO $9001 \mathrm{w}$ znacznym stopniu może zmienić wizerunek lotniska oraz pomóc w uzyskaniu przez zarządzających wymaganych przez prawo certyfikatów i najwyższych standardów. Niezmiernie ważne jest, by system działał sprawnie i wpływał na poprawę jakości i bezpieczeństwa usług świadczonych przez porty lotnicze. Podróżni coraz częściej wybierają transport lotniczy, jako środek szybkiego przemieszczania się, co wpływa na wzrost przewoźników lotniczych a w konsekwencji wzrost konkurencji. Systemy wprowadzane przez zarządzających mogą być ważnym atutem przy wyborze danego portu lotniczego. 


\section{BIBLIOGRAFIA}

Compa T., Rajchel J., Załęski K. (2013), Bezpieczeństwo w lotnictwie w wybranych aspektach funkcjonowania portu lotniczego. Wydawnictwo Wyższej Szkoły Oficerskiej Sił Powietrznych, Dęblin.

Duszewski J. (2016), Wybrane aspekty funkcjonowania portów lotniczych i obstugi pasażerów. [w] Kwasiborska A. Bezpieczeństwo Transportu Lotniczego. Oficyna Wydawnicza ASPRA-JR. Warszawa.

Ejdys J., Kobylińska U., Lulewicz - Sas A. (2012), Zintegrowane Systemy Zarzadzania jakościa, środowiskiem i bezpieczeństwem pracy. Oficyna Wydawnicza Politechniki Białostockiej, Białystok.

Kalinowski Ł.M. (2009), Systemy Ochrony Portu Lotniczego przed atakami bezprawnej ingerencji na przyktadzie portu lotniczego Warszawa Okęcie. AON. Warszawa.

Klich E. (2011), Bezpieczeństwo Lotów. Wydawnictwo Naukowe Instytutu Technologii Eksploatacji - PIB, Radom.

Latzko W., Sanders D. M (1998), Cztery dni z dr Demingiem. Nowoczesna Teoria zarzadzania. Wydawnictwo Naukowo-Techniczne, Warszawa.

Łunarski J. (2008), Zarządzanie jakością. Standardy i zasady. Wydawnictwo Naukowo - Techniczne, Warszawa.

Norma PN-EN ISO 9001: 2015 Systemy zarzadzania jakościa. Wymagania.

Rajchel J., Grenda B., Nowak J., (2014), Bezpieczeństwo i zarządzanie kryzysowe w lotnictwie. Wydawnictwo Wyższej Szkoły Oficerskiej Sił Powietrznych, Dęblin.

Rozporzadzenie Ministra Infrastruktury z dnia 10 stycznia 2005 r. w sprawie Krajowego Programu Kontroli Jakości w zakresie ochrony lotnictwa cywilnego.

Sztucki J., Gąsior M., Zając G., Szczelina M. Zarządzanie bezpieczeństwem lotnictwa cywilnego. Skrypt dydaktyczny (Dostęp 12.11.2016r.).

Załęski K., Saletra N., Kowalska K. (2015), Wybrane aspekty bezpieczeństwa w transporcie. Wyższa Szkoła Oficerska Sił Powietrznych. Dęblin.

http://www.amw.gdynia.pl/library/File/ZN\%202010/16Zielinski\%20M.pdf?PHPSESSID=bd4f5e989e2d5863870e23c6e1857209 (Dostęp 22.12.2016 r.)

http://www.ulc.gov.pl/p1/247-aktualnosci/3714-pierwszy-certyfikat-lotniska-uzytku-publicznego-wydany-na-podstawie-nowych-przepisow-unijnych (Dostęp03.01.2017 r.)

http://gtl.com.pl/ (Dostęp 12.01.2017 r.)

http://www.katowice-airport.com/download/gtl_polityka_jakosci.pdf (Dostęp12.01.2017 r.)

https://www.katowice-airport.com/pl/lotnisko/polityka-bezpieczenstwa (Dostęp 12.01.2017 r.)

\section{QUALITY MANAGEMENT SYSTEMS AT AIRPORTS}

Abstract: Adequate level of safety is achieved by taking various measures, including the implementation of a safety management system services. Raising the bar is extremely important, because competition between airports is great. The aim is to show the quality management systems at airports. The method of critical literature review and case study.

Ensuring safety requires the fulfillment of legal requirements and the implementation of management systems in the area of security and quality of service. This is extremely important due to the fact that air transport is increasingly being used means of transport. Entering management systems helps to maintain security at the appropriate level and attracting new customers. This paper describes the operating systems at the International Airport Katowice in Pyrzowice.

Keywords: quality management systems, airport 